SokAL, R. R. and F. J. RohlF (1995): Biometry. $3^{\text {rd }}$ ed. W. H. FREEMAN and Company, San Francisco, 887p.

SwoFFord, D. L. and R. B. SELANDER (1989): BIOSYS-1: a computer program for the analysis of allelic variation in population genetics and biochemical systematics. Release 1.7. Illinoise Natural History Survey, IL.

TANi, N., N. Tomaru, M. ARAKI and K. OHBA (1996): Genetic diversity and differentiation in populations of Japanese stone pine (Pinus pumila) in Japan. Can. J. For. Res. 26: 1454-1462.

Tomaru, N. Y., Y. Tsumura and K. Ohba (1990): Inheritance of isozyme variants in Korean pine (Pinus koraiensis). J. Jap. For. Soc. 72: 194-200 (in Japanese with English summary).

Torres, E., J. M. IRIONdo and C. PÉREZ (2003): Genetic structure of an endangered plant, Antirrhinum microphyllum (Scrophulariaceae): Allozyme and RAPD analysis. Amer. J. Botany. 90(1): 85-92.

UyeKI, H. (1926): Corean Timber Trees, vol. 1. Ginkgoales and Coniferae. The Forestry Experiment Station, Government General of Chosen. 154p (in Japanese).
WANG, Y. Z. (ed.) (1995): Korean Pine Forest. Northeastern Forest University Press. Harbin, China. 503pp (in Chinese).

WRIGHT, S. (1951): The genetical structure of populations. Ann. Eugenics 15: 323-354.

WRIGHT, S. (1965): The interpretation of population structure by $F$-statistics with special regard to systems of mating. Evolution 19: 395-420.

Wright, S. (1978): Evolution and the Genetics of Populations, vol. 4. Variability Within and Among Natural Populations. University of Chicago Press, Chicago. USA.

YeH, F. C., R. C. YANG and T. Boyle (1999): POPGENE. Microsoft window-based freeware for population genetic analysis. Dept. of Renewable Resources. Univ. of Alberta. Edmonton, Alberta. Canada.

YI, J. S. (ed.) (2005): Korean white pine (Pinus Koraiensis) I. The Society for Korean White Pine. 150p.

\title{
Variation in Reproductive Phenology in a Pinus radiata D. Don Seed Orchard in Northern Spain
}

\author{
By V. Codesido ${ }^{1), *)}$, E. Merlo*) and J. Fernández-LóPez*)
}

(Received $4^{\text {th }}$ October 2005)

\begin{abstract}
Summary
Reproductive phenology was studied in a Pinus radia$t a$ seed orchard, located in northern Spain. Timing of flowering was determined on the basis of data recorded by visual observations made in 2000, 2001 and 2002 . The genetic and environmental factors affecting female and male phenology, as well as reproductive synchronization, were studied. The dates of beginning of the receptive phase and pollen shedding varied greatly from year to year but the variation on the sum of degree-days was low. In general, the flowering periods of the different clones overlapped. The clonal differences in the phenology of receptivity and pollen shedding were in most cases statistically significant. The time needed to reach flowering stages was under strong genetic control. Genetic control was stronger for the female than the male flowering process. However, correlations between years were stronger for male than for female flowering phenology. The male flowering clones that best synchronized with the females appeared to be those that started flowering earlier. The phenological overlap index varied greatly among clones, whether male or female, and also among years.
\end{abstract}

\footnotetext{
*) Departamento de Producción Forestal, CIFA Lourizán, Apt Correos 127, E-36080 Pontevedra, Spain.

1) Tlf: +34986805072, Fax: +34986856420, Email: vcodesido.cifal@ siam-cma.org
}

Key words: flowering receptivity, pollen shedding, reproductive synchronization, flowering phenograms, cumulative growing degree-days, phenological overlap index, SYNCHRO.SAS programme, clonal repeatibility, progeny test, genetic variation, genetic parameters, quantitative traits.

\section{Introduction}

Radiata pine is one of the most commonly planted exotic tree species in Galicia (northwest Spain). It occupies almost 60.000 ha (4\% of Galician forests) with an annual volume increment estimated at around $10^{6} \mathrm{~m}^{3}$. year $^{-1}$ (XUNTA DE GALICIA, 2001). Together with Pinus pinaster (324.000 ha) and Eucalyptus globulus (290.000 ha), it accounts for $90 \%$ of the Galicia forestry Industry. The main use for Pinus radiata timber is in the furniture industry and the trees are grown on a short rotation of some 16 to 30 years, depending on the fertility of the site. Production is approximately $600 \times 10^{3} \mathrm{~m}^{3}$ per year, making planting of these species a very attractive investment (DANS DEL VALLE, 1999). The demand for improved seed has warranted active breeding programmes.

Genetic improvement of $P$. radiata stock in Galicia was initiated in 1992 and has included phenotypic mass selection in plantations and use of this material for seed production in clonal seed orchards. A clonal radiata pine 
seed orchard was established in 1997 in Galicia to supply large quantities of genetically improved growing stock to this area. The main objective of a seed orchard is the production of genetically improved seed for reforestation purposes. The genetic quality of the seed is dependent on the fulfilment of certain criteria (ERIKSSON et al., 1973; WOESSNER and FrANKLIN, 1973; WEIR and ZoBEL, 1975) such as: a) clones are equally productive in male and female flowers, b) pollen shedding and female receptivity will coincide, c) crosses between different pairs of clones will be equally compatible, d) natural self-pollination will be insignificant.

Flowering phenology in an orchard is probably the single most important factor affecting outcrossing patterns (EL-KASSABY et al., 1988; ERICKSON and ADAMS, 1989; BURCZYK and PRAT, 1997). Thus, for tree improvement it is important to investigate the extent of phenological flowering variation in seed orchards and to make predictions about the genetic composition of the seed crop. Significant genetic variation in the time of flowering and in yield has previously been reported for Scots pine seed orchards (SAVOlainen et al., 1993; MÜller and ZIEHE, 1984), for Norway spruce (ERIKSSON et al., 1973; DANUSEvicIUS, 1987), for Douglas-fir (EL-KASSABY et al., 1984; Copes and SNIEzKo, 1991), for Picea mariana (O'REILly and PARKER, 1983) and radiata pine (GRIFFIN, 1984). The flowering phenology is more strongly affected by environmental factors (NIKKANNEN, 2001). Development of strobili depends on the temperatures to which they are exposed in the environment. Yearly variations in weather provide a physiological time scale that is biologically more accurate than calendar days.

The failure in synchronization of female flower receptivity and pollen shedding has a negative effect on the gene frequencies in the bulked seed produced in orchards (GRIFFIN, 1982; EL-KASSABY et al., 1984, 1988). A lack of synchronization in flowering can lead to nonrandom cross-fertilization, or cause a high number of empty seeds (BoEs et al., 1991) or even increased selfing (BHUMIBHAMON, 1978). Furthermore, quantification of phenological synchronization is fundamental in making decisions about orchard rouging, supplemental mass pollination or controlled pollinations within the orchard (El-Kassaby and Ritland, 1986; Blush et al., 1993).

Several different techniques have been developed for quantifying the degree of reproductive synchronization between all mating pairs of clones (Askew, 1988; Askew and Blush, 1990; XIE et al., 1994; GöMÖRY et al., 2000, 2003). A programme intended for SAS-Pc 6.12 (SYNCHRO.SAS) has recently been created to facilitate phenological data processing and to compute several phenological synchronization indices for each male-female combination and to enable construction of the male and female phenograms as well as other simple graphics that may help in the interpretation of phenological synchronization parameters (ZAS et al., 2003)

The main aims of the present study were to determine the phenological variation in female and male flowering in a Pinus radiata seed orchard, to describe the timing of female receptivity and pollen shedding, and to determine the extent to which environmental factors affect flowering phenology. Further aims were to study the genetic variation in flowering time and the heritability of those variables, to find out the extent of the synchronization between female receptivity and pollen shedding with the aim of quantifying the percentage of clones that do not interbreed, and to discuss the possible consequences of variation in reproductive phenology for the seed crop produced in the seed orchard.

\section{Materials and Methods}

The study was conducted in a radiata pine seed orchard located $10 \mathrm{~km}$ southeast of Santiago de Compostela, A Coruña, Spain $\left(42^{\circ} 49^{\prime} \mathrm{N}, 8^{\circ} 27^{\prime} \mathrm{W}, 270 \mathrm{~m}\right.$ above sea level). The orchard extends over approximately $2000 \mathrm{~m}^{2}$ and was planted in 10 randomized complete blocks. Each block contains one ramet of each of 62 clones. The orchard was established in 1997 by grafting clones intensively selected from plus trees in adult plantations in Galicia. The spacing is $1.5 \times 3 \mathrm{~m}$ (CoDESIDO and MERLo, 2001).

In 2000, 2001 and 2002, flower bud development was monitored in 25 randomly selected clones in the orchard. Between January and late March, the reproductive phenology of three male and three female marked branches on each tree was observed three times a week to determine the phenological stage of each strobili in each branch at a given date, until all pollen was released and seed cones were no longer receptive. The number of ramets per clone varied between 5 and 8 . Observations of flowering were made on the same trees each year, but not always on the same branches.

We distinguished four female stages and four male stages. The female stages were described by MATZIRIS (1994) as follows: stage 1, the female bud is increasing in size, becomes cylindrical, but is still completely covered by the bud scales ( $0 \%$ female receptivity); stage 2 , the apex of the enlarged cylindrical bud is opened and the first ovuliferous scales appear. At this stage the ovules are not receptive, but pollen grains may get inside the bud scales and if they survive they may to be able to take part in fertilization (20\% female receptivity); stage 3 , the scales of the female conelet are gradually separated and almost form right angles with the axis of the conelet. This is the stage of maximum receptivity $(100 \%)$, and stage 4 , the ovuliferous scales increase in size and thickness so that the strobili are no longer receptive ( $0 \%$ female receptivity).

The male stages were described as follows (CoDEsIDo and MERLO, 2001): stage 1, the round brown strobili are covered by the bud scales ( $0 \%$ pollen shedding); stage 2 , the male strobili burst through the bud scales and elongate ( $0 \%$ pollen shedding); stage 3 , the yellow strobili start shedding their pollen ( $100 \%$ pollen shedding) and stage 4 , end of pollen shedding. The male strobili wither and fall down ( $0 \%$ pollen shedding).

When there was more than one female flower per branch, we considered the beginning of female receptivity in all of the branch when some of the flowers reached the receptive stage. In the same way, receptivity was not considered to be concluded until all the female strobili of 
the branch had reached the end of the receptive stage (AskEw and BLUSH, 1990).

Phenological scores must be assessed on each branch in each ramet on each day of the study. The data were processed using the SYNCHRO.SAS programme, introducing the percentage of female receptivity or the percentage of pollen shedding associated with each phenological score and the date of the start and the end of assessment to obtain: the predicted beginning, end and duration of female receptivity and pollen shedding for each clone and for each ramet; the overall synchronicity graph, which represented the overall mean female receptivity and mean pollen shedding in all clones over time (e.g. MATZIRIS, 1994); the male and female phenograms presented as bands over time, which represented the relative female receptivity (or pollen shedding) of each clone at a given date (see e.g. Askew and BLush, 1990).

The climatic data for the study period were obtained from the Sergude weather station (located $200 \mathrm{~m}$ from the seed orchard) and consisted of mean daily temperatures recorded from December $1^{\text {st }}$ onwards (BoEs et al., 1991) including effective temperature (sum of degreedays $>+5^{\circ} \mathrm{C}$ ), between 2000 and 2002 , as well as mean daily precipitation during the flowering period.
The day of the year (from $1^{\text {st }}$ January) was used to identify the following variables: beginning and end of female receptivity and pollen shedding. The duration (number of days) was calculated by subtraction. These variables were analysed using the SAS GLM procedure (SAS Institute Inc. 1985) with individual analysis each year and combined analysis over more than one year.

The random models were respectively:

$X_{i j l}=\mu+C_{i}+B_{j}+\varepsilon_{i j l}$ for each year and

$X_{i j l k}=\mu+C_{i}+B_{j}+Y_{k}+C_{i}+Y_{k} \times \varepsilon_{i j l}$ for the combined analysis of variance over years for each trait, where $\mathrm{X}$ was the variable value in the ramet, $\mu$ was the overall mean, $\mathrm{C}$ was the random effect of the clone, $\mathrm{B}$ was the random effect of the block and $\varepsilon$ was the error. In the combined analysis, Y was the random effect of the year, $\mathrm{C} \times \mathrm{Y}$ was the interaction between clones and years. Variance components were estimated equating the type IV mean squares in the ANOVA table. Variable means, standard errors and coefficients of variation among clones were obtained (Table 2).

Broad sense heritability $\left(\mathrm{h}_{\mathrm{c}}^{2}=\right.$ clonal repeatibility) on a clonal mean basis were calculated for each year and for combined years respectively, as follows:

Table 1. - Basic statistics of traits under study: female and male onset, ending and duration for the three years.

\begin{tabular}{|c|c|c|c|c|c|c|c|c|c|c|c|c|c|c|c|c|}
\hline & & & & 2000 & & & & & 2001 & & & & & 2002 & & \\
\hline & Trait & Mean & Min & Max & SE & $\mathrm{CV}$ & Mean & Min & Max & SE & $\mathrm{CV}$ & Mean & Min & Max & SE & $\mathrm{CV}$ \\
\hline Female & Onset & 38.8 & 33.0 & 48.0 & 0.75 & 9.1 & 15.1 & 13.5 & 25.0 & 0.45 & 15.8 & 33.0 & 30.0 & 43.0 & 0.44 & 7.2 \\
\hline & Ending & 69.4 & 60.0 & 77.5 & 1.05 & 9.1 & 51.4 & 37.0 & 62.0 & 1.20 & 12.6 & 70.0 & 60.5 & 77.0 & 0.86 & 6.5 \\
\hline & Duration & 31.7 & 12.0 & 39.0 & 1.93 & 28.5 & 35.2 & 21.0 & 46.5 & 1.71 & 26.2 & 37.2 & 29.5 & 46.0 & 0.80 & 11.5 \\
\hline Male & Onset & 49.1 & 43.5 & 57.5 & 0.80 & 7.8 & 36.0 & 30.6 & 46.0 & 1.18 & 20.1 & 45.5 & 38.0 & 65.0 & 0.95 & 11.0 \\
\hline & Ending & 63.7 & 60.0 & 67.0 & 0.41 & 3.1 & 46.5 & 37.0 & 60.0 & 1.05 & 11.7 & 69.0 & 58.0 & 77.0 & 1.21 & 9.3 \\
\hline & Duration & 14.3 & 8.5 & 21.0 & 0.74 & 24.9 & 6.9 & 15.6 & 25.5 & 0.83 & 27.2 & 23.5 & 12.0 & 34.0 & 1.23 & 27.8 \\
\hline
\end{tabular}

a) 2000

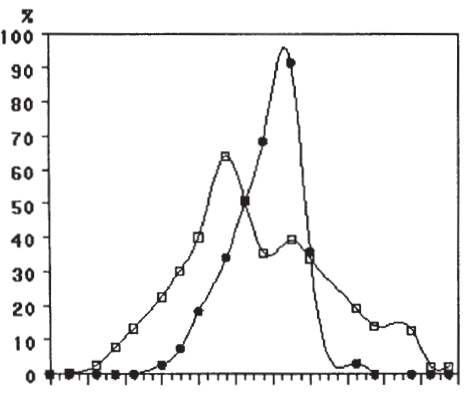

$\begin{array}{llllllllllll}33 & 37 & 41 & 45 & 49 & 53 & 57 & 61 & 65 & 69 & 73 & 77\end{array}$ b)2001

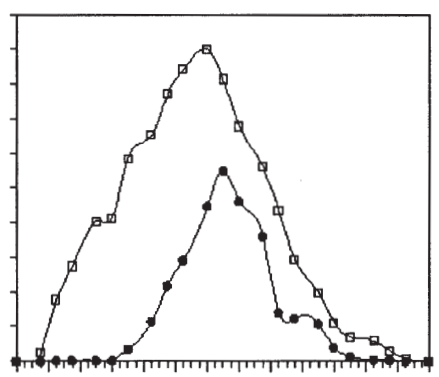

1216202428323640444852566064

Day of the year

- Pollen-shedding rate

c)2002

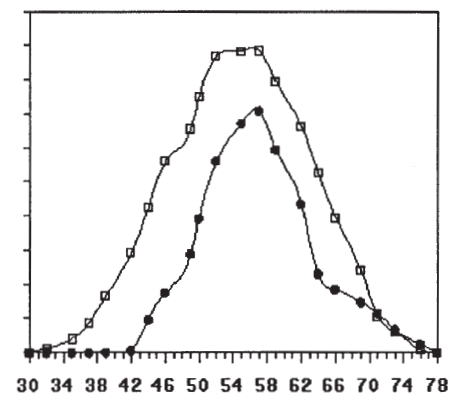

Figure 1. - Overall phenological overlap. The percentage of receptive strobili and shedding pollen strobili are shown. 
$\mathrm{h}_{\mathrm{c}}^{2}=\sigma_{\mathrm{c}}^{2} /\left(\sigma_{\mathrm{c}}^{2}+\sigma_{\mathrm{e}}^{2} / \mathrm{b}\right)$ and $\mathrm{h}_{\mathrm{c}}^{2}=\sigma_{\mathrm{c}}^{2} /\left(\sigma_{\mathrm{c}}^{2}+\sigma_{\mathrm{yc}}^{2} / \mathrm{b}+\sigma_{\mathrm{e}}^{2} / \mathrm{by}\right)$, where: $\sigma_{c}^{2}$ is the clonal variance; $\sigma_{e}^{2}$ is the variance due to error; $\sigma_{\mathrm{yc}}^{2}$ is the variance due to interaction of clones $\mathrm{x}$ years; $b$ is the harmonic mean of number of ramets per clone and $\mathrm{y}$ is the number of years.

Phenotypic correlations between all combinations of the variables were estimated as Pearson correlation coefficients $(r)$ and were used to determine the extent of relationships between flowering traits.

\section{Results}

Timing of flowering was determined in each year. The overall statistics of the initiation, cessation and duration of female receptivity and pollen shedding are shown in Table 1. It can be seen that in 2001 flowering was early in comparison with 2000 and 2002. There was a 13 day shift between 2000 and 2001 in the receptive period and the period of pollen release. There were no differences between 2000 and 2002. The variation in the flowering patterns from year to year can be observed in the graph of overall phenology synchronicity (Figure 1). The receptive period in the entire seed orchard was 31.73 , 35.24 and 37.16 days for the years 2000, 2001 and 2002, respectively; and the pollen shedding period was 14.26 , 6.9 and 23.46 days in 2000, 2001 and 2002, respectively. Maximum female receptivity was earlier than the peak of pollen shedding by 7 days in 2000 and by 2 days in 2001. Both peaks coincided in 2002. Note that in 2000, $15 \%$ of receptive female strobili remained in the seed orchard after pollen shedding stopped, so that $15 \%$ of the strobili were not pollinated in this year. This did not occur in the following two years.

In 2000 the receptive period extended from February $3^{\text {rd }}$ to March $18^{\text {th }}$ and the pollen shedding period from February $11^{\text {th }}$ to March $9^{\text {th }}$. The maximum number of receptive strobili $(65 \%)$ occurred on February $20^{\text {th }}$, one week before the maximum pollen release (98\%). In 2001 the receptive period extended from January $15^{\text {th }}$ to March $1^{\text {st }}$ and from January $25^{\text {th }}$ to February $25^{\text {th }}$ for pollen shedding. On February $5^{\text {th }}, 90 \%$ of all of the flowers monitored were receptive and only two days later,
$55 \%$ of male strobili were shedding pollen. In 2002 the pattern was very similar to that observed in 2000 , with the receptive period occurring between February $2^{\text {nd }}$ and March $17^{\text {th }}$, but on February $13^{\text {th }}$ the percentage of receptive strobili was $90 \%$. For male strobili, the period of pollen shedding occurred between February $11^{\text {th }}$ to March $17^{\text {th }}$ with a maximum of $70 \%$ on February $25^{\text {th }}$.

The length of the breeding season varied considerably among years but the variation in cumulative degreedays was low. The cumulative growing degree-days until the day of the female receptivity initiation was 210.19 in 2000, 245.25 in 2001 and 214.55 in 2002 and until the day of pollen shedding initiation, was 256.5 in 2000 , 280.0 in 2001 and 280.55 in 2002 . The peak of female receptivity occurred at 306.0 cumulative degree-days in $2000,313.5$ in 2001 and 311.38 in 2002. The peak pollen shedding occurred after 352.0 cumulative degree-days in $2000,330.75$ in 2001 and 325.75 in 2002. Pollen shedding began when the daily average precipitation decreased and finished abruptly when it started to rain again (Figure 2).

A summary of the results of ANOVA for all the variables measured in each year is shown in Table 2. Differences among clones were very large and statistically significant for all traits investigated and the values of sums of squares indicated the most important sources of variation. Differences between years were revealed by combined analysis of variance where a clone $\mathrm{x}$ year interaction was found, but this source of variation was less important than variation among clones when comparing MS (Table 2).

The broad sense heritability values based on clone means were very high for all traits among the three years, varying between 0.87 and 0.90 and between 0.88 and 0.92 for the onset and cessation of the receptive period, respectively. For pollen release, the values varied between 0.91 and 0.92 for the onset and between 0.85 and 0.95 for the cessation of the process. The values estimated from the combined over years analysis were very similar to values from analysis of single days, except for the male duration trait, indicating that there
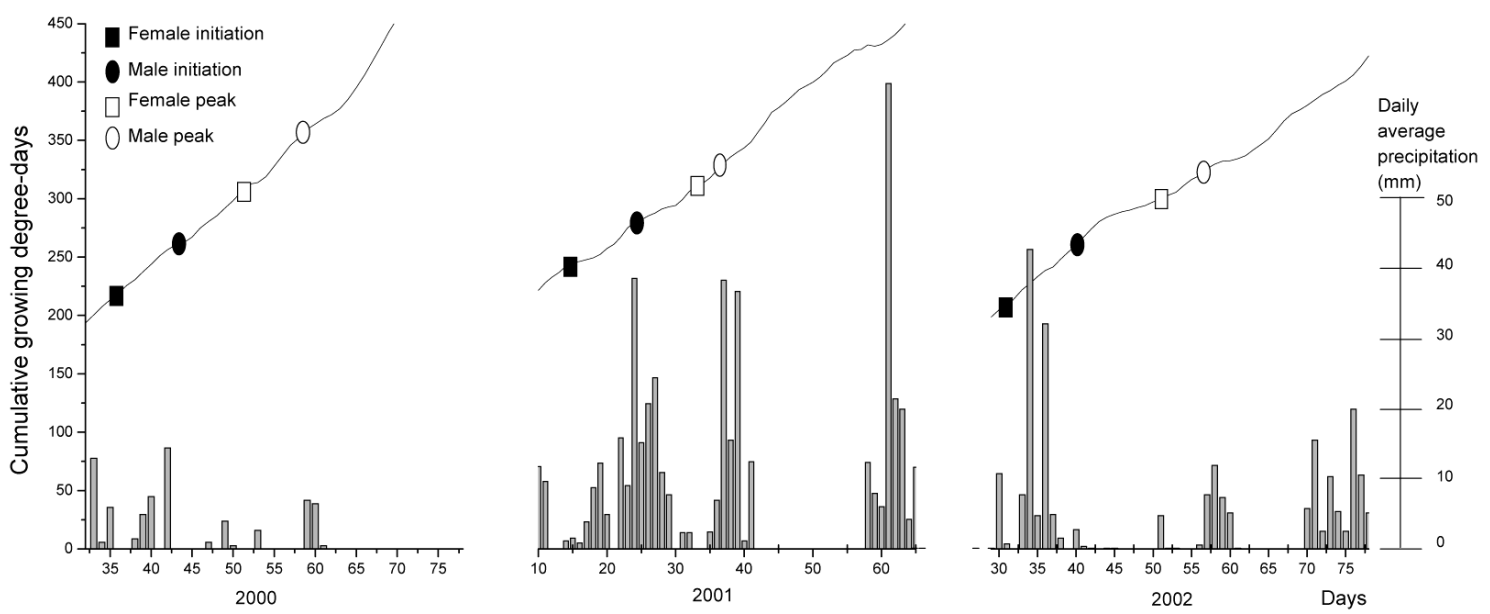

Figure 2. - Dates of female and male initiation $(\mathbf{\square}, \mathbf{0})$ and dates of the maximum percentage of female receptivity and male pollen shedding $(\square, \bigcirc)$ and their relation with climatological data during the flowering period in a radiata pine seed orchard. Line showed cumulative growing degree-days from December $1^{\text {st }}$ onwards. Columns represented daily average precipitation $(\mathrm{mm})$. 
Table 2. - MS, level of significance and clonal heritability for traits measured in single and combined year analysis.

\begin{tabular}{|c|c|c|c|c|c|c|c|}
\hline & & \multirow{2}{*}{\multicolumn{3}{|c|}{ Female }} & \multirow{2}{*}{\multicolumn{3}{|c|}{ Male }} \\
\hline & & & & & & & \\
\hline & & Onset & Ending & Duration & Onset & Ending & Duration \\
\hline \multirow[t]{4}{*}{2000} & Clone $^{1}$ & $165.40^{* * * *}$ & $271.20^{* *}$ & $146.40^{8 \% 3}$ & $121.10^{* * * * a}$ & $37.30^{* 38}$ & $72.50^{3 \% 8}$ \\
\hline & Block $^{2}$ & $56.30^{+*+4+k}$ & $84.99^{m+n}$ & $90.20^{m \times *}$ & $41.20^{\text {k*k* }}$ & $21.20^{* \omega *}$ & $36.99^{\text {...6\% }}$ \\
\hline & Error & 14.50 & 27.80 & 1.90 & 7.80 & 4.10 & 7.20 \\
\hline & $h_{c}^{2}$ & 0.88 & 0.92 & 0.83 & 0.92 & 0.85 & 0.63 \\
\hline \multirow[t]{4}{*}{2001} & Clone' & $282.10^{* * * *}$ & $229.60^{* * * *}$ & $130.20^{* * 8}$ & $193.99^{* * * *}$ & $228.10^{* * * *}$ & $26.60^{* * *}$ \\
\hline & Block $^{2}$ & $133.90^{\text {**** }}$ & $82.70^{* *}$ & $84.60^{* *}$ & $62.10^{\text {**:* }}$ & $68.99^{* * 8}$ & 6.20 \\
\hline & Error & 29.70 & 18.80 & 20.10 & 10.99 & 7.50 & 6.80 \\
\hline & $h_{c}^{2}$ & 0.87 & 0.90 & 0.81 & 0.92 & 0.95 & 0.67 \\
\hline \multirow[t]{4}{*}{2002} & Clone' & $219.30^{* * *}$ & $198.60^{* 4+4 t}$ & $113.30^{* * * *}$ & $219.30^{* *}$ & $158.9^{* * *}$ & $59.30^{* * *}$ \\
\hline & Block $^{2}$ & $85.40^{* * *}$ & $104.90^{* * *}$ & $89.70^{* * * *}$ & $83.40^{* * *}$ & $120.60^{* * * *}$ & $108.90^{* * * *}$ \\
\hline & Error & 20.30 & 12.80 & 15.60 & 14.60 & 16.10 & 16.60 \\
\hline & $h_{c}^{2}$ & 0.90 & 0.88 & 0.86 & 0.91 & 0.85 & 0.86 \\
\hline \multirow[t]{6}{*}{ Combined } & Clone $^{1}$ & $407.20^{* * *}$ & $379.40^{k * *}$ & $183.20^{* * *}$ & $410.20^{* 8 *}$ & $268.90^{* * *}$ & $66.40^{* * * *}$ \\
\hline & Block $^{2}$ & $85.99^{* * *}$ & $103.99^{* * *}$ & $122.20^{\text {*.*3 }}$ & $115.10^{* \ldots *}$ & $130.20^{* * *}$ & $49.90^{\text {*n. }}$ \\
\hline & Year $^{3}$ & $6102.99^{\text {s:k:k }}$ & $11596.99^{k: * * *}$ & $4216.50^{k: k: k}$ & $13816.60^{* * * *}$ & $8682.60^{* * * *}$ & $966.90^{\text {:k:kk }}$ \\
\hline & Clon x Year & $62.9^{* * * 8}$ & $49.20^{* * * *}$ & $65.99^{* * *}$ & $67.80^{* * *}$ & $85.40^{* * * *}$ & $57.99^{* * * x}$ \\
\hline & Error & 23.20 & 20.10 & 18.90 & 11.80 & 10.20 & 11.40 \\
\hline & $h_{c}^{2}$ & 0.93 & 0.94 & 0.83 & 0.92 & 0.84 & 0.32 \\
\hline
\end{tabular}

*** Statistically significant at $\mathrm{P}<0.0001$; ** Statistically significant at $\mathrm{P}<0.001 ;{ }^{1}$ Degrees of freedom: 24; ${ }^{2}$ Degrees of freedom: $9 ;{ }^{3}$ Degrees of freedom: 2

were no great changes in the relative ranking of clones from year to year (Table 3).

The year to year correlations for the initiation and cessation of reproductive stages were moderate and statistically significant (Table 3). The correlations between initiation and cessation of female receptivity within years were quite high, positive and statistically significant. Similar results were found for the initiation and cessation of pollen shedding. Moderate to high negative correlations between the initiation of reproductive stages and their respective durations were obtained. The correlations between initiation of female receptivity and pollen shedding were positive and statistically significant, except in 2000. Otherwise, the correlations between cessation of female receptivity and pollen shedding were moderate, positive and statistically significant, again except in 2000. There were no correlations between the duration of female receptivity and pollen shedding within years (data not shown).
Table 3. - Year to year PEARSON's coefficients of correlation between flowering traits investigated.

\begin{tabular}{|c|c|c|c|c|c|c|c|}
\hline & Female & \multicolumn{2}{|c|}{2000} & \multicolumn{2}{|c|}{2001} & \multicolumn{2}{|c|}{2002} \\
\hline Male & & Onset & Ending & Onset & Ending & Onset & Ending \\
\hline \multirow[t]{2}{*}{2000} & Onset & & $0.66^{* * * *}$ & $0.50^{* * *}$ & $0.38^{* * * *}$ & $0.38^{* * * *}$ & 0.28 \\
\hline & Ending & $0.51^{* * *}$ & & $0.41^{* * * *}$ & $0.33^{* * * *}$ & $0.32^{* * *}$ & $0.25^{*}$ \\
\hline \multirow[t]{2}{*}{2001} & Onset & $0.41^{* * *}$ & $0.32^{* * * *}$ & & $0.66^{* * *}$ & $0.31^{* * *}$ & $0.34^{* * *}$ \\
\hline & Ending & $0.42^{* * *}$ & $0.33^{* * *}$ & $0.87^{\text {**** }}$ & & $0.27^{* * *}$ & $0.42^{* * *}$ \\
\hline \multirow[t]{2}{*}{2002} & Onset & $0.42^{* * * *}$ & $0.30^{* * * *}$ & $0.44^{* * * *}$ & $0.42^{* * * *}$ & & $0.61^{*}$ \\
\hline & Ending & $0.44^{* * *}$ & $0.39^{* * * *}$ & $0.37^{* * *}$ & $0.32^{* * *}$ & $0.66^{* * *}$ & \\
\hline
\end{tabular}

*** Statistically significant at the $\mathrm{P}<0.0001$; ** Statistically significant at $\mathrm{P}<0.001$. 
The large variation among clones in the initiation, cessation and duration of female receptivity and pollen shedding was also evident in the phenograms (Figure 3). The differences between the clones that were earliest and latest in starting the receptive period were between 8 and 19 days for the beginning of the female flowering. The same clone (clone 41) was earliest in starting the receptive period in all three years (February $1^{\text {st }}$ in 2000 , January $12^{\text {th }}$ in 2001 and January $31^{\text {st }}$ in 2002), and clone 09 was always the latest, reaching this stage on February $20^{\text {th }}$ in 2000, January $20^{\text {th }}$ in 2001 and February $10^{\text {th }}$ in 2002. Pollen shedding always began some days after the commencement of seed-cone receptivity
( 8 days in 2000, 11 days in 2001 and 11 days in 2002). Differences between and within clones were found in both male and female flowering time. The length of the time period during which receptive female strobili and pollen shedding occurred varied between clones.

In the phenograms (Figure 3 ) the boxes of the righthand-side show the average clonal overlap indices. The $\mathrm{PO}_{\mathrm{ij}}$ index (Askew and BLUSH, 1990), which is a quantitative measure of the proportional symmetry of the female and male phenograms, is the ratio of the common area to the maximum area between the female and male phenograms summed across all registered days and for each pair of clones. The variation in the index a)2000. Female
Male

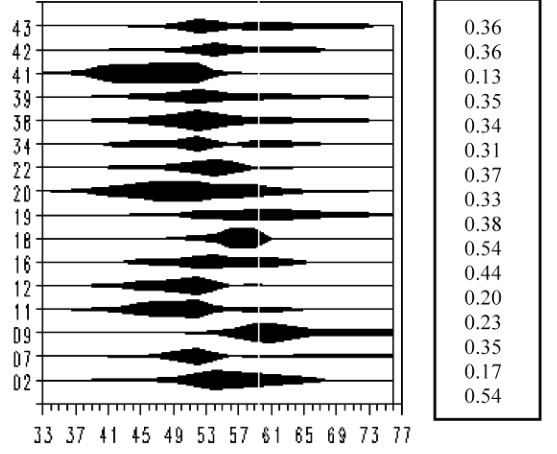

b)2001

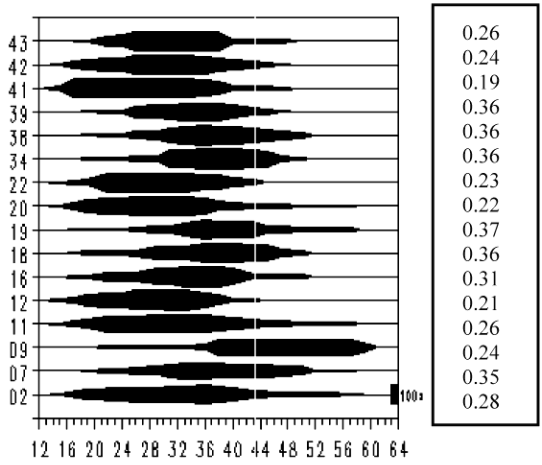

c)2002

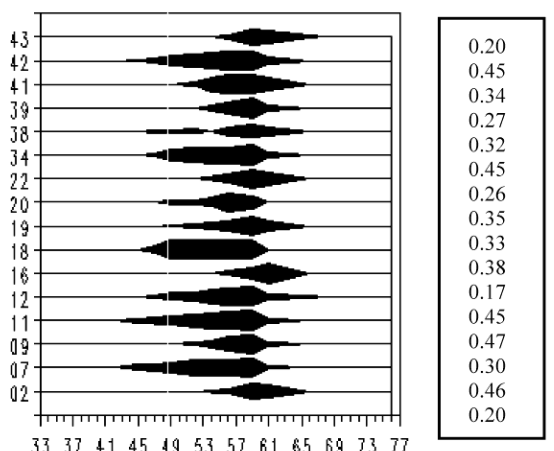

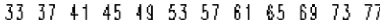

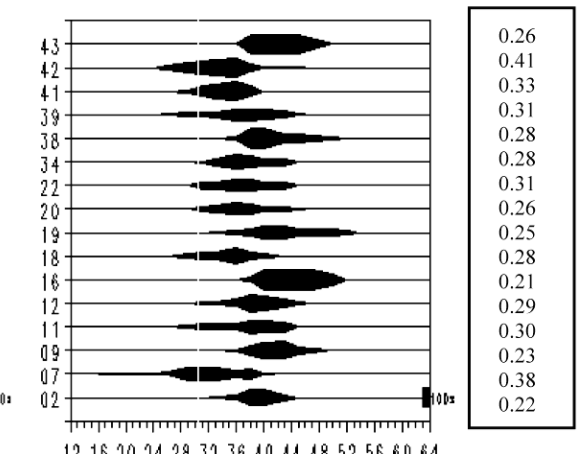

1216202428323640444852566064 
calculated for female flowering ranged between 0.13 and 0.54 in 2000, between 0.19 and 0.37 in 2001 and between 0.23 and 0.51 in 2002 . For male flowering, the index ranged between 0.17 and 0.47 in 2000, 0.21 and 0.41 in 2001 and between 0.05 and 0.58 in 2002. The distributions of the phenological overlap index (Figure 4 ) varied greatly between years with averages of 0.34 in $2000,0.29$ in 2001 and 0.42 in 2002. The synchronization of male and female phenology for each pair of mating clones varied between 0.01 and 0.74 in 2000; between 0.07 and 0.52 in 2001 and between 0 and 0.82 in 2002. In general, the clone 42 was the best overlapping male flowering clone and the best female one was the 18. Most asynchrony occurred in 2001. In 2000 and 2001 every female clone was able to be pollinated by every male clones and every male clone was able to pol-

a) 2000 .

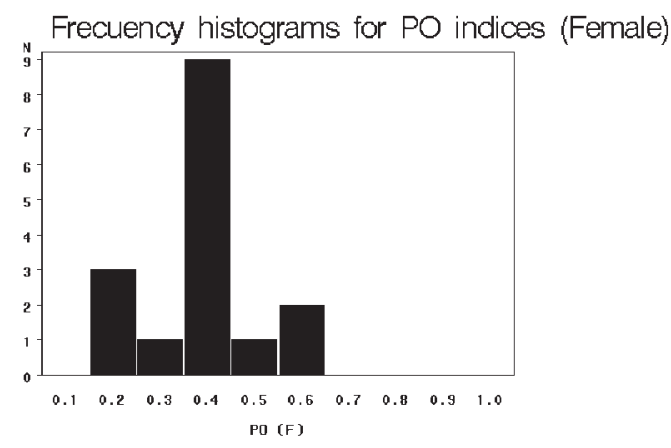

b) 2001

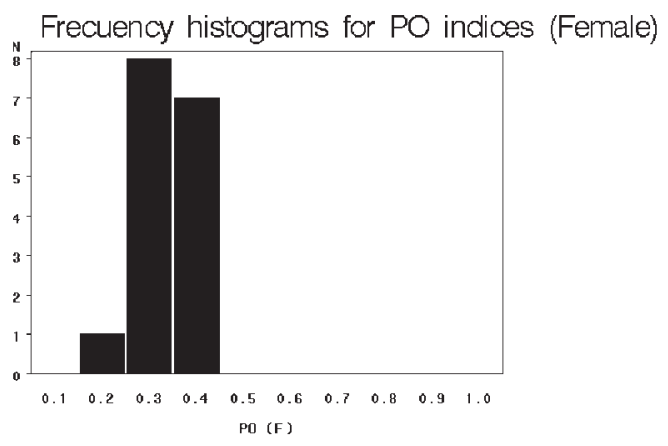

c) 2002

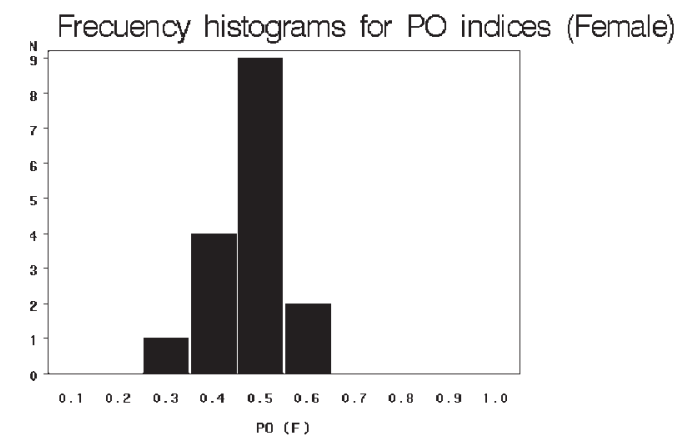

Figure 4. - Frequency histograms for PO indices. linate every female clones. Nevertheless, in 2002 five pair of mating clones were not possible. There was no pollen available in clone 38 when clones 11, 12, 20, 39 and 41 were receptive. In 2000, $43 \%$ of the pairs of clones had $\mathrm{PO}_{\mathrm{ij}}$ values that were higher than the seed orchard mean, in 2001 it was $45 \%$ and in 2002 it was $55 \%$. In general, most clones were synchronized, the overlap indices generally being higher than 0.40 .

\section{Discussion}

Flowering phenology was characterized by a steady increase in the number of receptive trees and the absence of pollen donors at the beginning of the receptive period. After a few days of female receptive period in the seed orchard, there was a steady increase in
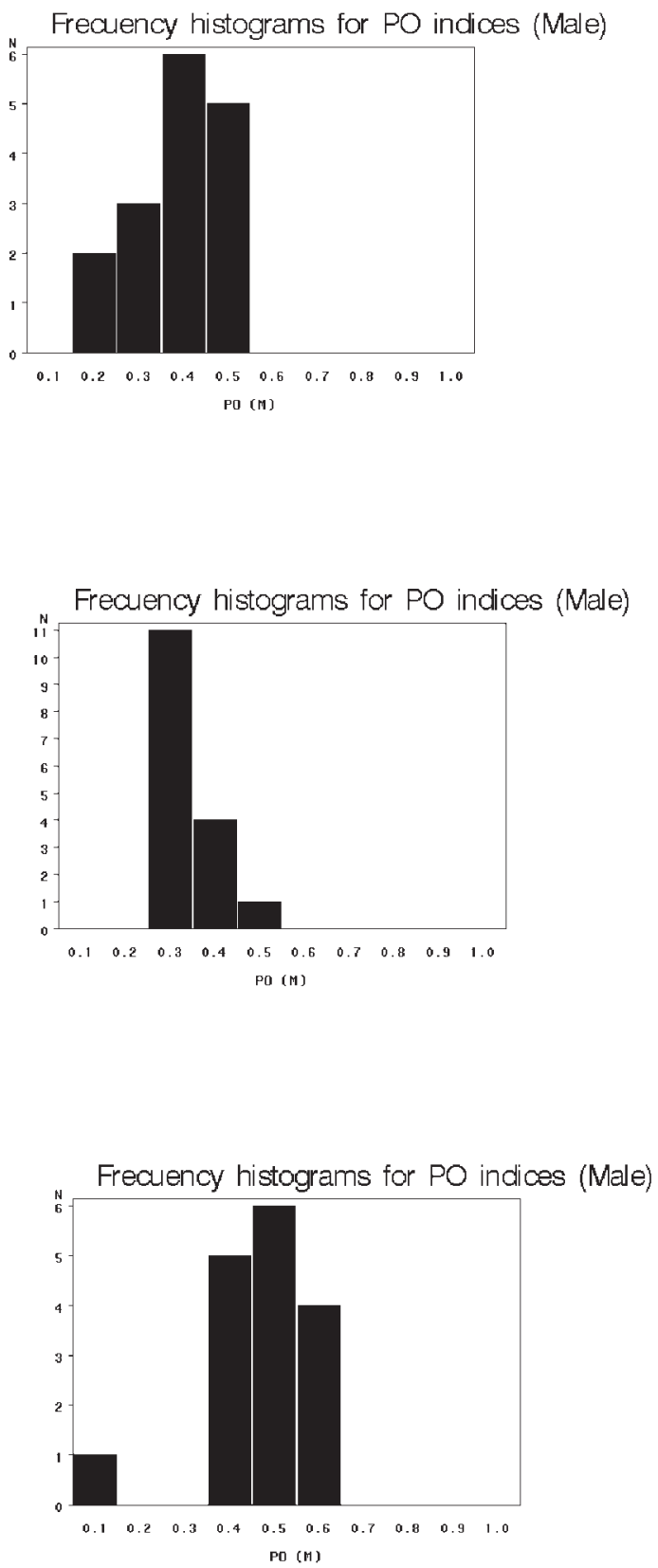
pollen production with a peak in pollen shedding. Although in many pines male and female flowering phenology starts at about the same time (BLUSH et al., 1993), female flowering in radiata pine started a few days before male flowering (GRIFFIN, 1984) as in Pinus nigra (LARIO et al., 2001) and in Scots pine (SARVAS, 1962; BurCzYK and CHALUPKA, 1997). The duration of the receptive period in the seed-orchard under study (between 32 and 37 days) was closer to the 35 days found for radiata pine in New Zealand (LILL and SwEET, 1977) and also for other conifer species such as Scots pine (31 days, Jonsson et al., 1976), Douglas-fir (30 days, El-Kassaby et al., 1984) and Sitka spruce (33 days, EL-KASSABY et al., 1990).

The timing of flowering appeared to depend to a large extent on the sum of degree-days (SARVAS, 1967; CHUNG, 1981; BoEs et al., 1991). The results for different years were very close and similar to data obtained by PARANTAINEN and PULKINNEN (2003) in the second year of phenological study of a Scots pine seed orchard (217.1 d.d. for female flowering initiation and 243.2 for the onset of male flowering). It may be necessary for a certain cumulative temperature threshold to be reached before to the flowering process begins in the orchard and for the maximum percentage of female flowers to be receptive and pollen release to occur. The differences between years were associated with environmental factors (note that the flowering process started on February $3^{\text {rd }}$ in 2000 and on February $2^{\text {nd }}$ in 2002 but 20 days before in 2001 , because this year was warmer than 2000 and 2002). JoNsSON et al. (1976) pointed out that temperature conditions were largely responsible for the variations in pollen dispersal from year to year and also there were of greater importance for the onset and duration of the receptivity than the date in Scots pine. The beginning of anthesis is positively correlated with the cumulative degree-days of the preceding growing season (LUOMAJOKI, 2003). Moreover, CoPES and SNIEZKO (1991) observed that cool March temperatures tended to compress the length of the breeding season and thereby increase the possibility of panmixia in a Douglas fir orchard. Rainfall may also interfere with the phenology process from year to year. The quantity and rate of pollen shed is dependent on relative humidity and rainfall patterns (EBELL and SCHMIDT, 1964). The percentage of strobili shedding pollen was greater than the percentage of female receptive strobili in 2000 but not in 2001 and in 2002, possibly because of the rainfall patterns. Conditions were drier in 2000 than in 2001 and 2002. When it rained during the flowering process (as in 2001 and 2002), pollen shedding was interrupted, there was a gradual build-up to peak flowering and the percentage of strobili shedding pollen diminished because some strobili had lost their ability to flower; if flowering was not interrupted by rainfall, there tended to be a rapid build-up until maximum shedding (2000). Photoperiod may also have been an influencing factor as it has been found to affect male and female flowering to different degrees (GYERTICH, 1967).

The statistical differences among clones in terms of the dates of receptivity and pollen shedding initiation in every year studied along with the clonal heritability val- ues, showed that the time needed to reach these flowering stages was under strong genetic control. Ranking of clones according to the number of days required from December $1^{\text {st }}$ until receptivity or initiation of pollen shedding showed a high degree of similarity in all the three years. This indicates that clones that flowered early in one year usually did so in other years; late flowering clones were also consistently late in flowering. Similar results have been also reported for several conifers such as radiata pine (GRIFFIN, 1984), loblolly pine (AsKEw, 1988), Scots pine (JoNsSON et al., 1976), Douglas-fir (EL-KASSABY et al., 1984) and Black pine (MATZIRIS, 1994). The same occurred with the cessation of receptivity and pollen shedding. Genetic control was stronger in the female than the male flowering process, as in Pinus nigra (MATZIRIS, 1994). The small differences between years are probably due to the fact that the strobili under study did not occupy exactly the same position on the graft each year and is well known that the onset of flowering in the strobili growing on the southfacing part of the graft were early with a short duration of receptivity, whereas the strobili on north-facing part exposure showed late onset and prolonged receptivity (JONSSON et al., 1976; NiKKANEN, 2001).

The large variation among clones in the stages of flowering and their duration times was evident from the results of the analysis of variance (Table 2). The repeatability values were very high and constant among years, except for the duration of pollen release. It may be that environmental factors had a stronger effect on male than on female phenology, as in a Norway spruce seed orchard in southern Finland (NIKKANEN, 2001). The length of the pollen shedding period may vary depending on the weather in a specific year. Although the results of the combined analysis showed repeatability for this trait in terms of mean results for clones, this was the only one factor that showed large differences from the heritability in the separate analyses, indicating that duration of pollen release may depend on the weather in a specific year. Repeatability among ramets within clones for female receptivity and initiation of pollen shedding were very similar to those observed by Matziris in Pinus nigra (1994) and in Douglas fir by ERICKSON and ADAMS (1989).

The year to year correlation coefficients for the dates of receptivity or pollen shedding initiation, and the dates of cessation of those stages were positive, moderate and statistically significant, again demonstrating that the clone ranking was very similar in the years under study. There were no correlations between years for duration of traits, so that the duration of flowering stages of the clones was not consistent from year to year and that strongly affected by environmental fluctuations. There were high negative correlations between the date of initiation of female receptivity or the date of initiation of pollen shedding and their respective durations. This indicated that the clones beginning pollen release early do so for a longer time than clones beginning pollen release later. Clones with pollen available for a relatively long period of time are more likely to have their genes transmitted to progeny than clones with pollen available for only a short time (BoEs et al., 
1991). The female clones that showed early onset of the flowering process were also receptive for longer because they must be receptive until the initiation of pollen shedding so that they can be pollinated. The duration of the female receptivity depended on the existence of pollen in the air because this stage would finish when the pollen grains penetrate between the ovuliferous scales and reach the pollen chamber of the ovules (MATZIRIS, 1994), and we found significant small positive differences between the date of initiation of receptivity and the date of initiation of pollen shedding each year. This means that the female strobili must try to adapt their receptive period to the time of pollen shedding to be able to be pollinated, because it is clear that female strobili cannot be pollinated if there is no pollen in the air and that clones with receptive flowers when maximum quantities of pollen are available can be more heavily pollinated than those with flowers that became receptive before or after that time. Similarly, clones that become receptive too late cannot be pollinated and the strobili would be receptive until they dried up and fell down.

The synchronization of each clone was characterized by the phenological overlap indices. The index provided us with a tool for tracking the development of the young seed orchard, showing increasing values from year to year (Askew and Blush, 1990). During the three years under study, we observed a gradual shift in flowering phenology, probably due to the juvenility of the seed orchard, with synchronization between female receptivity and pollen shedding periods improving with time. The progressive synchronization over the years is also evident in Figure 1. Variation among clones in synchronization of flowering production is found to occur in nearly all first generation seed orchards (SARVAS, 1962, 1968; SwEET, 1975; El-KASSABY et al., 1984; EL-KASSABY and REYNOLDS, 1990). Having a measure of the flowering synchrony of each clone with the remainder of the clones in the orchard is important for assessing the genetic value of the orchard crop (AsKew and BLUsH, 1990).

Stabilization between all pair of clones appeared to be reached, each clone could pollinate each other at some moment of the pollen shedding process and could also be pollinated by any clone in some moment of its receptivity phase. In $2000,19 \%$ of all possible combinations among 25 clones showed $\mathrm{PO}>0.5$, this percentage increased to $34 \%$ in 2002 , but in 2001 it fell to only $0.9 \%$ because, 2001 was a very warm rainy year and the breeding season was unusually long, 55 days compared with 40 days in 2000 and 2002, and produced more deviations from pancmitic equilibrium. In Douglas-fir, greater genetic efficiency was found in seed orchards when the breeding seasons were preceded by 3 or 4 weeks of cooler than normal weather (FASHLER and SzIKLAI, 1980; Copes and SNIEZKo, 1991) and, potential outcross efficiency may be $30 \%$ less in the orchards when warmer than normal temperatures occur 3 to 4 weeks preceding floral bud opening. The indices varied greatly among any one male or female parent and also among years. The overall seed orchard PO index value was 0.34 in 2000, 0.29 in 2001 and 0.42 in 2002. BurCKZYCK and CHALUPKA (1997) reported averages of 0.41 and 0.40 dur- ing two consecutive years in a 17 year old Scots pine seed orchard, results that are also consistent with the data obtained by ToRREs (2003) for a Pinus pinaster seed orchard in Spain. In 2002 the orchard reached desirable PO values, except for clone ID38 which was severally affected by Rhyacyonya buoliana the summer before and all its ramets appeared to be unhealthy. This was the only clone in 2002 that could not pollinate some of the other clones. If we eliminate this clone from the orchard we could obtain good flowering synchronization, with an orchard mean $\mathrm{PO}$ value about 0.6. In general, the best overlapping male flowering clones appeared to be those clones that started flowering earlier (i.e. clones 11, 42; Figure 3). Nevertheless, the highest overlap indices for female flowering were observed for intermediate flowering clones (i.e. 2, 39, Figure 3) as in Scots pine (BURCKZYCK and CHALUPKA, 1997). This indicates that the early and late flowering clones had lower potential outcross efficiency than the clones with more intermediate floral phenology. It was very interesting to verify that those clones with lower male PO indices were those with the higher female PO indices and vice versa. It may be very difficult to make decisions about which clones to use in the future.

We can conclude that there was significant genetic variation among clones in terms of male and female flowering process. The earliness of pollen release and female receptivity were under strong genetic control, and the precocity ranking was very similar from year to year. The reproductive synchronization of the seed orchard was not perfect, but improved each year. The PO values were useful for following the development of young seed orchards until reaching reproductive stability.

\section{Acknowledgements}

This study was financially supported by project: INIA SC99-028. We thank Dr. RAFAEL ZAS for his explanations of the SAS.SYNCHRO programme. We also thank nursery workers MARIANO DíAZ ARNEdo, RICARdo FERRADÁS Crespo, Enrique Diz Dios, María Soledad Barcala Iglesias, María Isabel Juncal Pintos, María Luisa Blanco Moledo and Pilar Soto Peleteiro for their dedicated work

\section{Literature}

Askew, G. R. (1988): Estimation of gamete pool compositions in clonal seed orchards. Silvae Genetica 37(5-6): 227-232.

Askew, G. R. and D. BLush (1990): Short note: an index of phenological overlap in flowering for clonal conifer seed orchards. Silvae Genetica 39(3-4): 168-171.

Bhumibhamon, S. (1978): Studies on Scots pine seed orchards in Finland with special emphasis on the genetic composition of the seed. Commun. Inst. For. Fenn. 94(4): 1-118.

Blush, T. D., D. L. Bramlett and Y. A. El-Kassaby (1993): Reproductive phenology of seed orchards. In: Advances in Pollen Management (D. L. BRAmlett, G. R. Askew, T. D. Blush, F. E. BRIDGwater, J. B. JETt, eds.), USDA Agriculture Handbook 698, Washington DC, USA. $15-23$. 
Boes, T. K., J. R. BRANDLE and W. R. LovetT (1991): Characterization of flowering phenology and seed yield in a Pinus sylvestris clonal seed orchard in Nebraska. Canadian Journal of Forest Research 21: 1721-1729.

BurczyK, J. and W. ChAlupka (1997): Flowering and cone production variability and its effect on parental balance in a Scots pine clonal seed orchard. Ann. Sci. For. 54: 129-144.

BurCzYK, J. and D. PRAT (1997): Male reproductive success in Pseudotsuga menziesii (Mirb). Franco: the effect of spatial structure and flowering characteristics. Heredity 79: 638-347-144.

Chung, M. S.(1981): Flowering characteristics of Pinus sylvestris L. with special emphasis on the reproductive adaptation to local temperature factor. Acta Forestalia Fennica 169: 1-68.

Codesido, V. and E. MERLO (2001): Caracterización fenológica del huerto semillero de Pinus radiata de Sergude. III Congreso Forestal Español. Actas del Congreso. Tomo III: $69-74$.

Copes, D. L. and SNiezko, R. A. (1991): The influence of floral bud phenology on the potential mating system of a wind-pollinated Douglas-fir orchard. Canadian Journal of Forest Research 21: 813-820.

Dans del Valle, F., F. J. Fernández de Ana-Magán and A. Romero García (1999): Manual de Selvicultura del pino radiata en Galicia. Proxecto Columella. Universidade de Santiago de Compostela. pp. 86.

DANUSEVICIUS, J. (1987): Flowering and seed production of clones and their stimulation in seed orchards. Forest Ecology and Management 19: 233-240.

EBELL, L. F. and R. L. SCHMidT (1964): Meteorological factors affecting conifer pollen dispersal on Vancouver Island. Can. Dep. For. Publ. No. 1036.

El-Kassaby, Y., A. M. K. Fashler and O. Sziklai (1984): Reproductive phenology and its impact on genetically improved seed production in a Douglas-fir seed orchard. Silvae Genetica 33: 120-125.

EL-KASSABY, Y. A. and K. RitLAND (1986): The relationship of outcrossing rate to reproductive phenology and supplemental mass pollination in a Douglas-fir seed Orchard. Silvae Genetica 35: 240-244.

El-Kassaby, Y., K. Ritland, A. M. K. Fashler and D. DEVITT (1988): The role of reproductive phenology upon mating system of a Douglas fir seed orchard. Silvae Genetica 37(2): 76-82.

El-KASSABY, Y. and S. ReYnoldS (1990): Reproductive phenology, parental balance and supplemental mass pollination in a Sitka spruce seed orchard. Forest Ecology and Management 31: 45-54.

ERIKSson, G., A. Jonsson and D. LindGREN (1973): Flowering in a clonal trial of Picea abies Karst. Stud. For. Suc., 110: $5-45$.

ERICKSON, V. J. and W. T. ADAMS (1989): Matins success in a costal Douglas fir seed orchard as affected by distance and floral phenology. Canadian Journal of Forest Research 19: 1248-1255.

FASHLER, A. M. and O. SzIKLAI (1980): The importance of flower phenology in seed orchard designs. Forestry Chronicle 56: 237-241.

GIERTYCH, M. M. (1967): Analogy of the differences between male and female strobiles in Pinus to the differences between long- and short-day plants. Canadian Journal of Botany 45: 1907-1910.

GömÖRY, D., R. BRUCHANIK and L. PAUle (2000): Effective population number estimation of three Scots pine (Pinus sylvestris L.) seed orchards based on an integrat- ed assessment of flowering, floral phenology, and seed orchard design. Forest Genetics 7(1): 65-75.

GöMÖRY, D., R. BRUChaniK and R. LONGAUER (2003): Fertility variation and flowering asynchrony in Pinus sylvestris: consequences of the genetic structure of progeny in seed orchards. Forest Ecology and Management, 174: $117-126$.

GRIFFIN, A. R. (1982): Clonal variation in Radiata pine seed orchards. I. Some flowering, cone and seed production traits. Australian Forest Research 12: 295-302.

GRIFFIN, A. R. (1984): Clonal variation in Radiata pine seed orchards. II. Flowering phenology. Australian Forest Research 14: 271-281.

Jonsson, A., I. EKBERG and G. ERIKSSON (1976): Flowering in a seed orchard of Pinus sylvestris L. Stud. For. Suec. $135 \mathrm{pp}$.

Lario, F. J., E. Merlo, J. Peñuelas and L. Gil (2001): Variabilidad clonal de la fenología reproductiva y producción floral. Participación clonal en un huerto semillero de Pinus nigra Arnold Salzmanni (Dunal) Franco. III Congreso Forestal Español. Actas del Congreso. Tomo III: 539-545.

LiLl, B. and G. Sweet (1977): Pollination in Pinus radiata. New Zealand Journal of Forestry Science 7(1): 21-34.

LUOMAJOKI, A. (1993): Climatic adaptation of Scots pine (Pinus sylvestris L.) in Finland based on male flowering phenology. Acta For. Fenn. 237: 1-27

MATZIRIS, D. I. (1994): Genetic variation in the phenology of flowering in Black pine. Silvae Genetica 43(5/6): 321-328.

MÜlleR-StarcK, G. and M. Ziehe (1984): Reproductive systems in conifer seed orchards. 3. Female and male fitnesses of individual clones realized in seeds of Pinus sylvestris L. Theoretical and Applied Genetics 69: $173-177$.

NiKKANEN, T. (2001): Reproductive phenology in a Norway spruce seed orchard. Silva Fennica 35(1): 39-53.

O'REILly, C., W. H. PARKER and J. E. BARKER (1983): Effect of pollination period and strobili number on random mating in a clonal seed orchard of Picea mariana. Silvae Genetica 31: 90-94.

Parantainen, A. and P. Pulkinnen (2003): Flowering and airbone pollen occurrence in a Pinus sylvestris seed orchard consisting on northern clones. Scandinavian Journal of Forest Research 18: 111-117.

SARVAS, R. (1962): Investigations on the flowering and seed crop in Pinus sylvestris. Com. Inst. For. Fenn. 53(4), 188pp.

SARVAS, R. (1967): Climatological control of flowering in trees. In: Proceedings of the $14^{\text {th }}$ IUFRO Congress, 4-9 Sept. 1967, Müchen. Pap.3. Deutscher Verband Forstlicher Forschungsanstalten, Freiburg, pp. 15-30.

SARVAS, R. (1968): Investigations on the flowering and seed crop in Picea abies. Comm. Inst. For. Fenn. 67(5): $5-84$.

SAS InstituTe, INC. (1985): SAS User's guide: statistics. Version 5. SAS Institute, Inc., Cary, NC. 956pp.

SAVolainen, O., K. KäRKKÄINEN, A. HARJU, T. NikANNEN and M. Rusanen (1993): Fertility variation in Pinus sylvestris: a test of sexual allocation theory. American Journal of Botany 80: 1016-1020.

SwEET, G. B. (1975): Flowering and seed production. In: Seed Orchards. For. Comm. Bull. $\mathrm{N}^{\circ} 54$, London, pp $72-82$.

TORRES, A. B. (2003): Variabilidad genética de la semilla obtenida en el huerto semillero de Pinus pinaster AIT. 
De Sergude, Boqueixón (A Coruña). Trabajo de Investigación Fin de Carrera. Universidad de Santiago de Compostela. $85 \mathrm{pp}$.

WeIR, R. and B. ZoBel (1975): Advanced generation seed orchards. In: Seed Orchards. For. Comm. Bull. $\mathrm{N}^{\circ} 54$, London, pp 118-127.

Woessner, R. A. and E. C. Franklin (1973): Continued reliance on wind-pollinated southern pine seed orchards- is it reasonable? In: R. J. DinUs, B. A. Thielges and O. O. Wells (Editors), Proc. $12^{\text {th }}$ Southern Tree Improvement Conf., June 1973. Louisiana State Univ., Baton Rouge, pp 64-73.
Xie, C. Y., J. Woods and M. SToenr (1994): Effects of seed orchard inputs on stimating effective population size of seedlots - a computer simulation. Silvae Genetica 43(2-3): 145-154.

XunTA DE Galicia (2001): O monte galego en cifras. Xunta de Galicia, Dirección Xeral de Montes e Medio Ambiente Natural, Santiago de Compostela, Spain, 227 p.

ZAS, R., E. MERLo and J. FERnÁNDEZ-LóPez (2003): Synchro: A SAS program for analysing the floral phenological synchronisation in seed orchards. Silvae Genetica 52(5-6): 212-215.

\section{Buchbesprechung}

Molecular Genetics and Breeding of Forest Trees. Von SANDeep Kumar und Matthias Fladung (Editors). Food Products Press, New York, London, Oxford, 2004, xx + 436 S., ISBN 1-56022-959-4, Preis: \$ 89.95.

Das vorliegende Buch präsentiert einen umfassenden Überblick über die aktuelle Forschung auf dem Gebiet der Molekularbiologie bei Forstbäumen. Moderne Methoden der Biotechnologie, welche bei krautigen Pflanzen längst zur Routine wurden, werden mit erheblich höherem Aufwand nun auch bei Forstbäumen angewandt. KUMAR und FLADUNG, beide tätig am Institut für Forstgenetik und Forstpflanzenzüchtung an der Bundesanstalt für Forst- und Holzwirtschaft in Großhansdorf, engagierten die bekanntesten Wissenschaftler im Bereich der Forstbiotechnologie aus der ganzen Welt um über transgene Bäume, funktionale und strukturelle Genomanalysen von Bäumen auf dem neusten Stand der Wissenschaft zu informieren. Das Buch ist unterteilt in vier Kapitel. Kapitel 1 beinhaltet Themen zur funktionellen Genomanalyse von Forstbäumen. Dieses Kapitel enthält neben einer Einführung in die funktionelle Genomanalyse Abschnitte zu EST (expressed sequence tags) Datenbanken und Proteomanalysen, sowie einen eigenen Abschnitt über das Transkriptom bei ectomykorrizaler Symbiose. Wohl das wichtigste Produkt der Forstindustrie ist Holz. Kapitel 2 ist komplett den molekularen Mechanismen der Holzbildung gewidmet. Im Detail werden Cellulose- und Ligninbiosynthese beschrieben. Versuche, in welchen die Lignin- bzw. Cellulosegehalte durch Überexpression bzw. Ausschalten von bestimmten Genen des Phenylpropanstoffwechsels manipuliert wurden, wurden ausführlich erläutert, da speziell für die Papierherstellung hohe Cellulosegehalte und geringe Ligningehalte wünschenswert sind. Transgene Bäume werden aller Voraussicht nach in Zukunft helfen, den steigenden Holzbedarf zu bedienen ohne auf Primärwälder zurückgreifen zu müssen. Erwähnenswert sind die in vitro Studien zur Holzbildung. Kapitel 3 beschäftigt sich ausführlich mit der Transformation von Forstbäumen. Zum einem geht es um anwendungsbezogene Forschung, wie die Erhöhung von Insektenresistenzen bzw. Veränderung der Blütenbildung und die
Transformation von Koniferen. Zum anderen geht es um Sicherheitsfaktoren in der Nutzung transgener Bäume. Besonders bei langlebigen Pflanzen, wie Bäume es sind, ist die Stabilität der Transgenexpression von besonderem Interesse. Gentechnik-Gegner unterstreichen häufig die Antibiotikaresistenzen in transgenen Pflanzen, welche bei der Transformation die Selektion transgener Individuen erleichtern. Neueste Techniken ermöglichen nun Transformationen ohne Verwendung von Antibiotikaresistenzmarkern. Kapitel 4 enthält Informationen zur Genomkartierung von Forstbäumen. Die einzelnen Abschnitte konzentrieren sich auf Genomkartierungen von Koniferen bzw. Populus spp. und australischen Akazienarten. Es wird deutlich dargestellt, wie verschiedenste Marker bei der Züchtung die Selektion auf bestimmte Merkmale (quantitative trait loci and qualitative trait loci) wesentlich erleichtern und v.a. beschleunigen. Auch wird das Klonieren von gesuchten Genen durch Genomkarten vereinfacht.

Bäume stellen einen relativ geringen Anteil der molekularbiologischen Forschung, aufgrund eindeutiger Nachteile im Vergleich zu krautigen Pflanzen (nicht oder nur unter hohem Zeitaufwand transformierbar, langsames Wachstum). In diesem Buch erfolgt eine Zusammenstellung sämtlicher molekularbiologischer Methoden, die eine erfolgreiche Anwendung bei Forstbäumen fanden. Alle wesentlichen Aspekte der molekularen Genetik und Züchtung bei Forstbäumen sind in diesem Band angesprochen. Dieses Buch eignet sich hervorragend für Studenten und Wissenschaftler, die im molekularbiologischen Bereich der Forstbiologie tätig sind.

Zusammenfassend läßt sich sagen, daß das Buch „Molecular Genetics and Breeding of Forest Trees“ anhand von Übersichtsartikeln und zahlreichen Abbildungen und Tabellen die wichtigsten und aktuellen molekularbiologischen Entwicklungen ganz spezifisch bei Forstbäumen anschaulich beschreibt und an Fallbeispielen mit temperaten als auch tropischen Bäumen erläutert.

B. Miller (Freiburg)

Herausgeberin: Bundesforschungsanstalt für Forst- und Holzwirtschaft: Schriftleitung: Institut für Forstgenetik und Forstpflanzenzüchtung, Siekerlandstrasse 2, D-22927 Grosshansdorf — Verlag: J. D. Sauerländer's Verlag, Finkenhofstrasse 21, D-60322 Frankfurt a. M. Anzeigenverwaltung: J. D. Sauerländer's Verlag, Frankfurt am Main. Satz: Satz- und Grafikstudio König, Marburg — Druck: ADN Offsetdruck, Battenberg — Printed in Germany. 